\title{
KONVERTER ARUS SEARAH TIPE BUCK DENGAN RANGKAIAN PEMICU MIKROKONTROLLER ARDUINO UNTUK APLIKASI GENERATOR TERMOELEKTRIK
}

\author{
Ali Mashduuqi ${ }^{*}$, Mochammad Facta dan Bambang Winardi \\ Departemen Teknik Elektro, Universitas Diponegoro \\ Jl. Prof. Sudharto, SH, Kampus UNDIP Tembalang, Semarang 50275, Indonesia \\ ${ }^{*}$ E-mail: mr.alimsh@gmail.com
}

\begin{abstract}
Abstrak
Generator termoelektrik merupakan salah satu sumber energi terbarukan yang mudah untuk didapatkan. Modul termoelektrik dapat mengkonversi energi panas menjadi energi listrik tegangan arus searah, energi listrik tegangan arus searah ini dapat digunakan sebagai sumber energi listrik. Penggunaan konverter arus searah pada generator termoelektrik termasuk dalam aplikasi daya rendah (Low Power Application). Dalam Tugas Akhir ini, dirancang konverter arus searah tipe buck dengan menggunakan kontroller arduino sebagai rangkaian pembangkit sinyal PWM dalam kondisi tanpa umpan balik dan dengan umpan balik tegangan. Umpan balik tegangan mampu menjaga nilai tegangan pada nilai yang dikehendaki. Berdasarkan hasil pengujian, rangkaian konverter arus searah tipe buck dapat menghasilkan tegangan dalam kondisi loop terbuka dengan nilai efisiensi rata-rata sebesar $80,16 \%$. Berdasarkan hasil pengukuran, rangkaian buck converter dengan umpan balik tegangan, nilai tegangan keluaran dapat dijaga pada nilai 45 Volt dengan tegangan keluaran rata-rata sebesar 4,45 Volt dengan nilai efisiensi rata-rata buck converter dengan umpan balik sebesar $81.68 \%$.
\end{abstract}

\section{Kata kunci: Termoelektrik,Konverter Arus Searah, Umpan Balik, Buck Converter}

\begin{abstract}
Thermoelectric generator is one of the renewable energy sources that is easy to obtain. The thermoelectric module can convert heat energy into electrical energy direct current voltage, the electrical energy of this direct current voltage can be used as a source of electrical energy. The use of direct current converters on thermoelectric generators is included in the low power application. In this final project, a direct current converter buck type is designed using an Arduino controller as a PWM signal generator circuit in conditions without feedback and with voltage feedback. Voltage feedback is able to maintain the voltage value at the desired value. Based on the test results, direct current converter buck type circuits can produce voltage in open loop conditions with an average efficiency value of $80.16 \%$. Based on the measurement results, buck converter circuit with voltage feedback has the output voltage valuewhich can be maintained at a range of value 4-5 Volts with an average output voltage of 4.45 Volts. The average buck converter efficiency value with feedback is $81.68 \%$.
\end{abstract}

Keywords: Thermoelectric, Direct Current Converter, Feedback, Buck Converter

\section{Pendahuluan}

Pada perkembangan teknologi kini, banyak dicanangkan berbagai energi alternatif dan energi baru terbarukan untuk mengurangi dampak terjadinya pemanasan global. Namun ketersediaan sumber energi baru terbarukan di Indonesia masih belum termanfaatkan secara maksimal. Penelitian ini dilakukan berdasar pemanfaatan sumber energi baru terbarukan, khususnya panas bumi untuk menghasilkan energi listrik, yaitu menggunakan generator termoelektrik (TEG) sebagai sumber energi alternatif. Generator termoelektrik dapat mengkonversikan perbedaan temperatur menjadi besaran listrik secara langsung namun TEG masih memiliki beberapa kekurangan, yakni memiliki nilai efisiensi yang rendah yaitu 10\%[1]. Hal-hal yang membuat efisiensi berkurang adalah panas yang dikonveksikan pada TEG tidak terserap secara sempurna serta sistem pendinginan yang tidak sempurna sehingga TEG tidak dapat bekerja secara maksimal.

Pemanfaatan konverter arus searah dalam aplikasi daya rendah (Low Power Application) seperti termoelektrik generator. Konverter arus searah tipe buck converter dapat digunakan berbagai aplikasi seperti sebagai catu daya motor dan charger aki. Pada penelitian [2] konverter arus searah digunakan sebagai catu daya motor. IC TL494 digunakan sebagai pengontrol utama. Penelitian [3] 
dibahas konverter arus searah tipe buck converter sebagai charger aki dengan pemicuan menggunakan IC TL494. Kedua penelitian ini tidak menggunakan umpan balik (feedback) tegangan sebagai umpan balik tegangan keluaran dari buck converter . Kedua penelitian ini dalam kondisi open loop control, sehingga dalam penelitian tersebut tidak mampu untuk merespon terhadap perubahan beban. Pada penelitian [4], dibahas konverter DC-DC tipe Buck dengan umpan balik tegangan sebagai pengisi akumulator. Pada penelitian tersebut, rangkaian kontrol PWM beserta umpan balik tegangan menggunakan IC TL494. Pada penelitian [5], dibahas tentang konverter DC-DC Tipe Buck dengan pemutus tegangan otomatis dengan berbasis IC TL494. Keempat penelitian ini masih menggunakan rangkaian kontrol konvensional yaitu rangkaian kontrol IC TL494. Penggunaan kontrol IC TL494 kurang user friendly bila dibandingkan dengan kontrol mikrokontroler Arduino. Mikrokontroler Arduino memiliki banyak fitur yang memungkinkan untuk pembacaan sensor melalui konversi sinyal analog menjadi digital melalui fitur ADC (Analog to Digital Converter), fitur input/output yang memungkinkan untuk menambah tampilan LCD, serta fitur dari pin digital Arduino yang mampu membangkitkan PWM (Pulse Width Modulation).

Pada penelitian ini dirancang rangkaian konverter arus searah tipe buck converter berbasis mikrokontroller Arduino. Mikrokontroler Arduino Nano digunakan sebagai rangkaian kontrol sekaligus sebagai peralatan pengatur umpan balik yang akan mengatur nilai keluaran dari konverter arus searah tersebut. Sensor tegangan juga mampu membaca keluaran tegangan dari buck converter yang selanjutnya diumpan balik ke Arduino Nano.

Pada penelitian tugas akhir ini akan dirancang modul perangkat keras konverter arus searah tipe buck dengan umpan balik tegangan dan tanpa umpan balik tegangan untuk pengisian beban.

Tugas Akhir ini bertujuan dalam perancangan rangkaian konverter arus searah tipe buck converter serta menganalisis pengaruh tanpa umpan balik tegangan rangkaian konverter arus searah tipe buck converter dan pengaruh umpan balik tegangan pada keluaran konverter arus searah tipe buck converter.

\section{Metode}

Perancangan Tugas Akhir ini terdiri dari rangkaian penyearah, rangkaian konverter arus searah tipe buck, rangkaian kontrol pembangkit sinyal PWM dan beban.

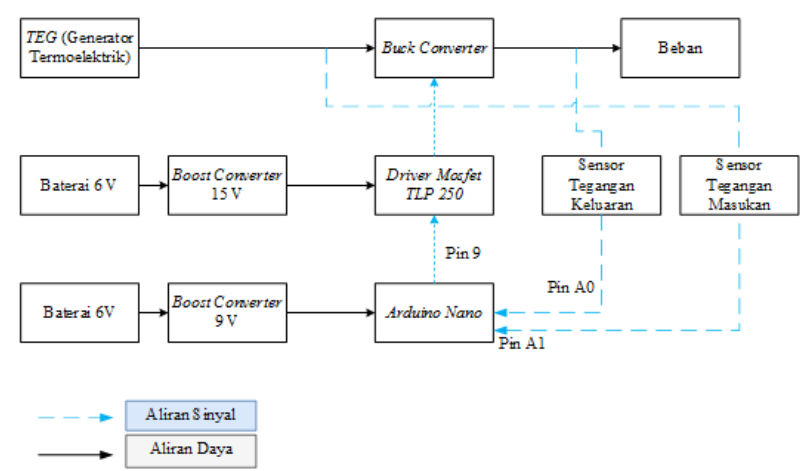

Gambar 1. Blok Diagram Alat

2.1. Konverter DC-DC tipe Buck

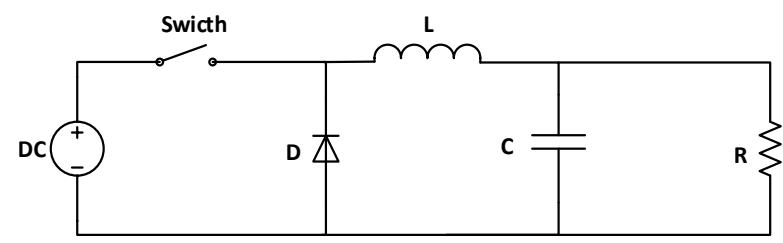

Gambar 2. Rangkaian Konverter Buck

Konverter arus searah tipe buck terdiri atas komponenkomponen penyusun yang terdiri dari:

1. Sumber tegangan arus searah (DC) Generator Termoelektrik

Sumber DC untuk suplai rangkaian buck didapat dari rangkaian TEG Array. Sumber tegangan tersebut memberikan tegangan sebesar 9-12 volt.

2. Saklar

Komponen pensaklaran yang digunakan pada rangkaian buck converter ini adalah MOSFET. MOSFET yang dipakai adalah tipe IRFZ44N yang mempunyai tegangan Drain-Source 55 volt dan kemampuan arus Drain sebesar 49 A[6]. Nilai tersebut mencukupi untuk dipakai pada rangkaian buck converter dengan tegangan masukan 9-12 volt.

3. Dioda

Dioda yang dipakai adalah dioda MUR1560 yang memiliki spesifikasi tegangan 600 volt dan arus $15 \mathrm{~A}$ serta waktu pemulihan 60ns[7]. 
4. Induktor

Induktor yang digunakan pada rangkaian buck converter ini adalah induktor jenis batang yang dibuat dari kawat tembaga yang dililitkan pada inti ferit. Induktor yang digunakan memiliki nilai lebih besar dari $\mathrm{L}_{\mathrm{MIN}}$ agar buck converter bekerja dalam kondisi Continous Conduction Mode(CCM)[8].

$$
L_{M I N}=\frac{(1-D) \cdot R}{2 f}=\frac{(1-0.5) \cdot 100}{2.25000}=0.001 \mathrm{mH}
$$

Nilai induktor yang digunakan pada rangkaian buck converter adalah $0,59 \mathrm{mH}$. Pemilihan nilai induktor lebih besar dari nilai induktor minimal $\left(\mathrm{L}>\mathrm{L}_{\min }\right)$ agar Buck Converter bekerja pada Continous Conduction Mode (CCM).

5. Kapasitor

Kapasitor berfungsi sebagai filter tegangan untuk membatasi ripple tegangan yang disebabkan penambahan nilai beban. Kapasitor yang digunakan pada rangkaian buck converter ini adalah $470 \mu \mathrm{F} 50$ volt.

$$
\begin{aligned}
& C=\frac{1-D}{8 L\left(\frac{\Delta V_{0}}{V_{0}}\right) f^{2}}=\frac{1-0.50}{8.0,69 \times 10^{-3} \cdot\left(\frac{0.01}{5}\right) 25000^{2}} \\
& C=84,7 \mu \mathrm{F}
\end{aligned}
$$

Nilai kapasitor hasil perhitungan adalah $84,7 \mu \mathrm{F}$, akan tetapi nilai kapasitor yang dipakai adalah $470 \mu \mathrm{F} 35 \mathrm{~V}$ karena nilai kapasitor hasil perhitungan tidak dapat ditemukan di pasaran.

\subsection{Rangkaian Kontrol}

Sistem buck converter yang dirancang pada generator termoelektrik ini membutuhkan suatu rangkaian kontrol yang berfungsi untuk mengakuisisi dan mengolah data tegangan keluaran dari buck converter untuk menjalankan proses umpan balik tegangan. Hasil dari pengolahan data pada rangkaian kontrol berupa sinyal PWM yang digunakan untuk pensaklaran MOSFET. Perancangan rangkaian kontrol dibagi menjadi 3 bagian yaitu, perancangan rangkaian pembangkit PWM yang menggunakan Arduino Nano, perancangan sensor tegangan masukan yang mampu membaca nilai tegangan dari keluaran TEG dan perancangan sensor tegangan keluaran dari buck converter sehingga tegangan dapat diumpan balikkan ke Arduino Nano untuk mengatur nilai PWM. Gambar 3 menunjukkan blok diagram dari perancangan rangkaian kontrol.

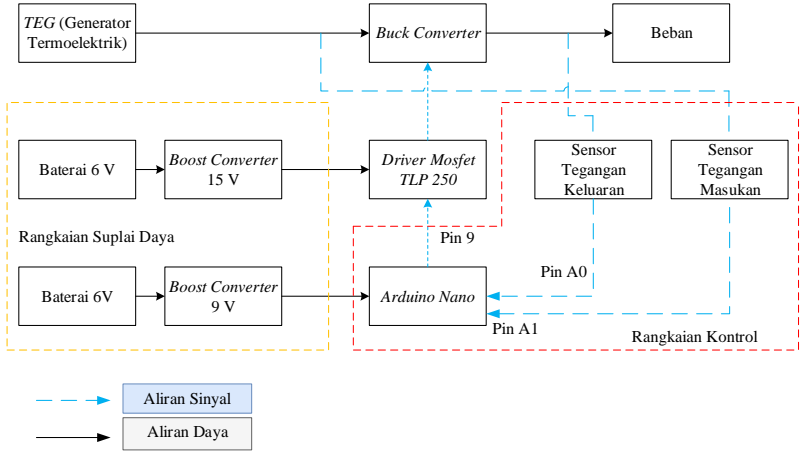

Gambar 3. Blok Diagram Rangkaian Kontrol

\subsubsection{Arduino Nano}

Arduino Nano merupakan rangkaian kontrol yang berfungsi mengolah data pembacaan tegangan dari masukan buck converter dan keluaran buck converter sehingga dapat diatur nilai PWM sesuai hasil pembacaan .

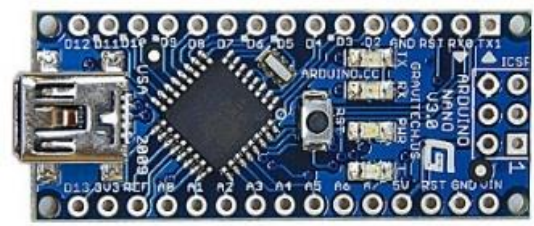

Gambar 4. Arduino Nano[9]

\subsubsection{Rangkaian MOSFET Driver}

MOSFET driver TLP250 digunakan untuk mengisolasi antara rangkaian kontrol dan rangkaian daya, TLP250 juga menguatkan level tegangan 5 volt yang dibangkitkan Arduino Nano menjadi level tegangan yang lebih tinggi dengan sistem ground terpisah dan mampu memicu MOSFET[10].

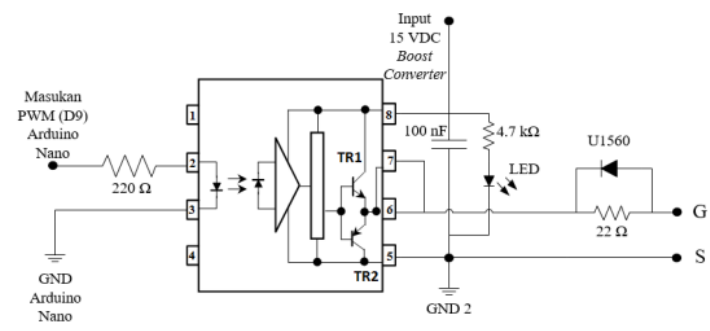

Gambar 5. Rangkaian TLP250. 


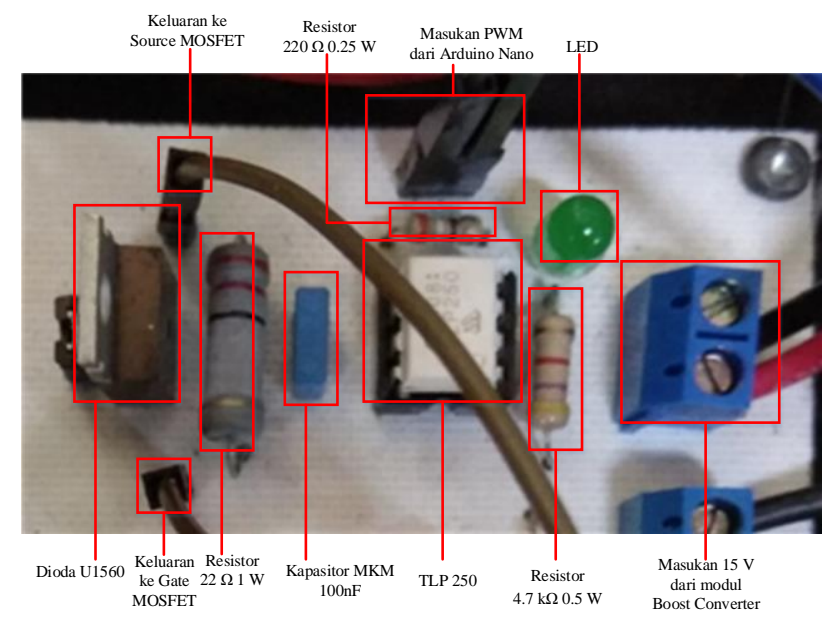

Gambar 6. Realisasi rangkaian TLP250.

\subsubsection{Sensor Tegangan}

Sensor tegangan yang digunakan adalah rangkaian pembagi tegangan menggunakan multiturnmeter. Output dari buck converter maksimal adalah 12 volt dibutuhkan multiturn 20k.

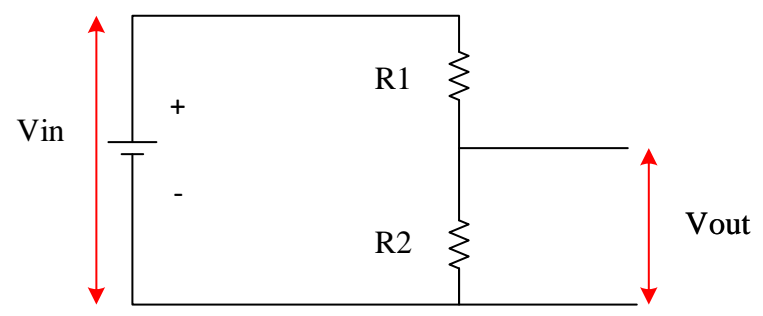

Gambar 7. Rangkaian sensor tegangan[10]

Pengaturan multiturn untuk menghasilkan tegangan Vout yang dapat dibaca Arduino. Pin analog arduino hanya bisa membaca tegangan dalam rentang $0-5 \mathrm{~V}$. Pada sensor tegangan keluaran, nilai yang masuk ke pin A0 diatur dengan dengan $2.18 \mathrm{~V}$.

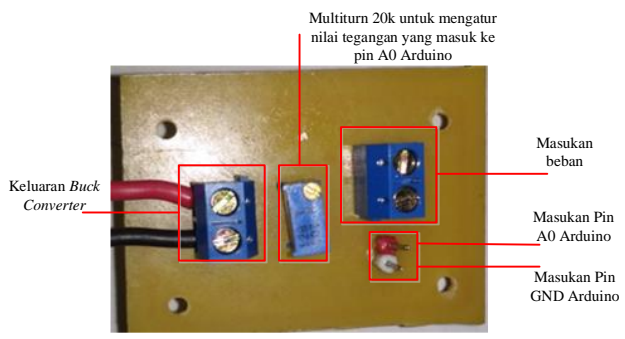

Gambar 8. Realisasi rangkaian sensor tegangan output.

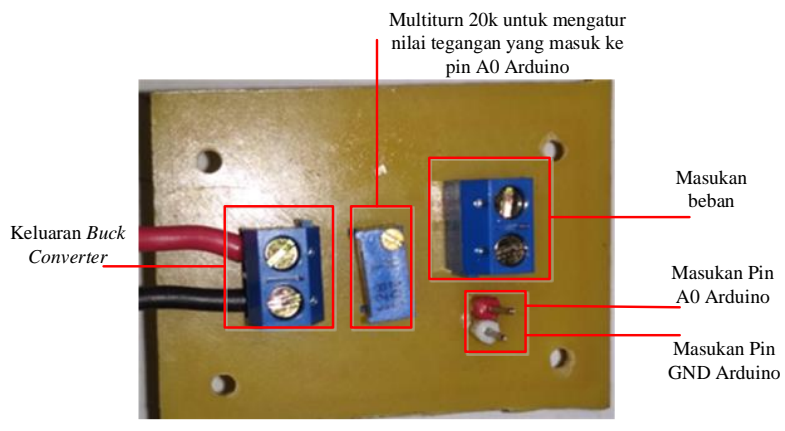

Gambar 9. Realisasi rangkaian sensor tegangan input.

Sensor tegangan perlu dikalibrasi perhitungannya untuk mendapatkan hasil yang sesuai dengan perancangan.

\section{Hasil dan Analisis}

\subsection{Pengujian Rangkaian Kontrol}

3.1.1. Pengujian Sumber Tegangan TEG

Pengujian sumber tegangan dilakukan untuk mengetahui besar nilai sumber tegangan yang dihasilkan dari modul termoelektrik yang dipasang secara seri. Bentuk dan besar tegangan dapat dilihat pada Gambar 10 sebagai berikut :

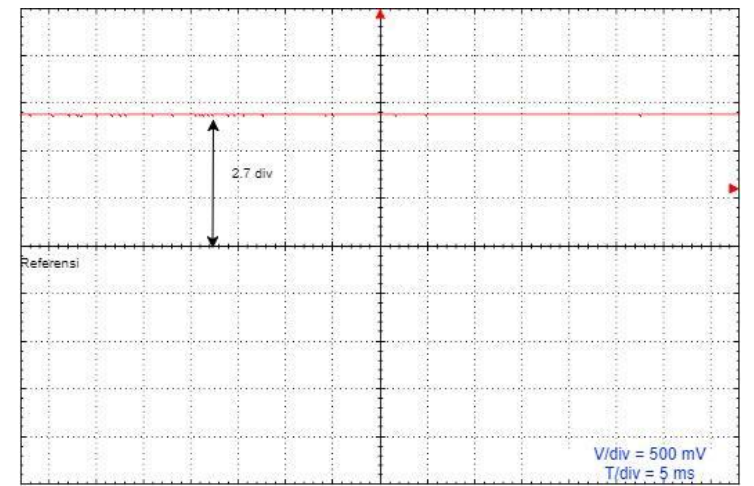

Gambar 10. Gelombang keluaran tegangan sumber TEG $\mathrm{V} / \mathrm{div}=\mathbf{5 0 0} \mathrm{mV}, \mathrm{T} / \mathrm{div}=\mathbf{5 0} \mathrm{ms}$.

Gambar 10 menunjukkan hasil pengujian tegangan TEG dengan tegangan sebesar :

$$
\begin{aligned}
& \mathrm{V}_{\text {TEG }}=2,7 \mathrm{div} \text { x } 500 \mathrm{mV} / \mathrm{div} \\
& \quad=13.5 \text { volt }
\end{aligned}
$$




\subsubsection{Pengujian PWM Arduino Nano}

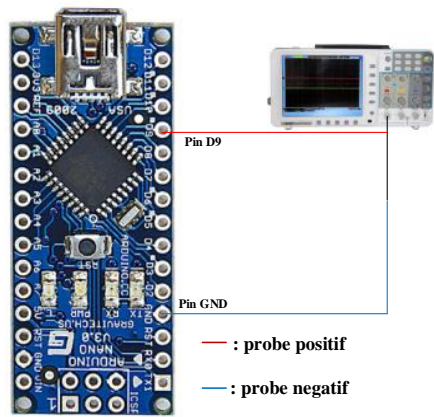

Gambar 11. Rangkaian pengujian PWM Arduino Nano.

Gambar 11 menunjukkan gelombang output pin PWM pada nilai duty cycle $10 \%$ dengan $\mathrm{t} / \mathrm{div}=20 \mu \mathrm{s}$ dan $\mathrm{V} / \mathrm{div}=2 \mathrm{~V}$. Level tegangan yang dihasilkan Arduino Nano adalah 5 volt.

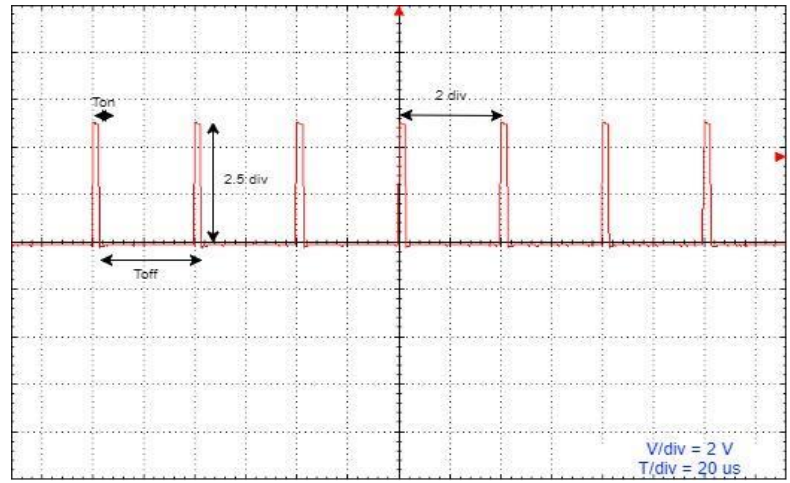

Gambar 12. Gelombang PWM pin 9 Arduino Nano dengan duty cycle $10 \%$

\subsubsection{Pengujian Rangkaian MOSFET Driver TLP250}

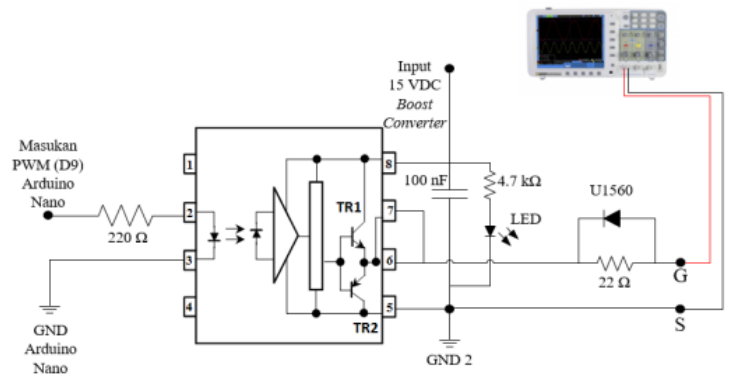

Gambar 13. Pengujian MOSFET Driver TLP 250 dengan Osiloskop

Gambar 14 menunjukan gelombang PWM output dari TLP250 pada duty cycle $10 \%$ dengan $\mathrm{t} / \mathrm{div}=20 \mu \mathrm{s}$ dan $\mathrm{V} /$ div $=5 \mathrm{~V}$. Level tegangan yang dihasilkan TLP250 adalah 15 volt yang cukup untuk memicu MOSFET IRFZ44N.

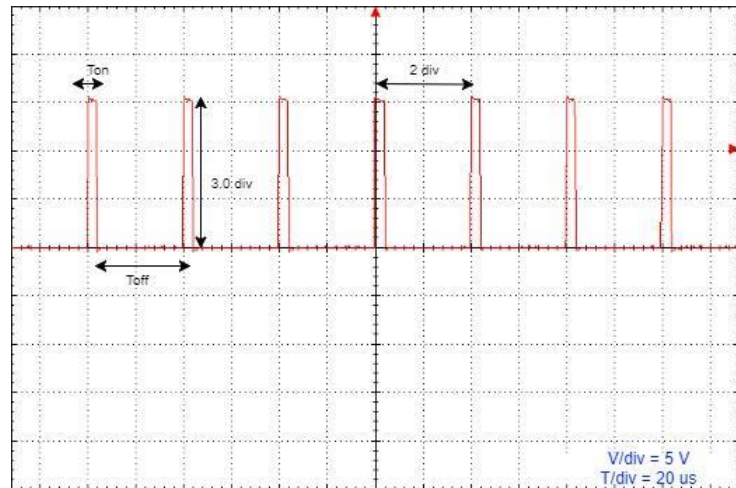

Gambar 14. Gelombang PWM TLP250 dengan duty cycle $10 \%$

\subsubsection{Pengujian Sensor Tegangan}

Pengujian sensor tegangan dilakukan dengan membandingkan nilai tegangan hasil pengukuran menggunakan sensor yang telah dibuat dibandingkan dengan tegangan hasil pengukuran menggunakan multimeter PC5000a. Pengujian sensor tegangan dilakukan dengan 10 buah variasi tegangan dari 3,34 volt sampai 15,43 volt. Pemilihan variasi tersebut untuk melihat nilai pembacaan sensor tegangan untuk rentang tegangan kerja dari buck converter yang akan digunakan.

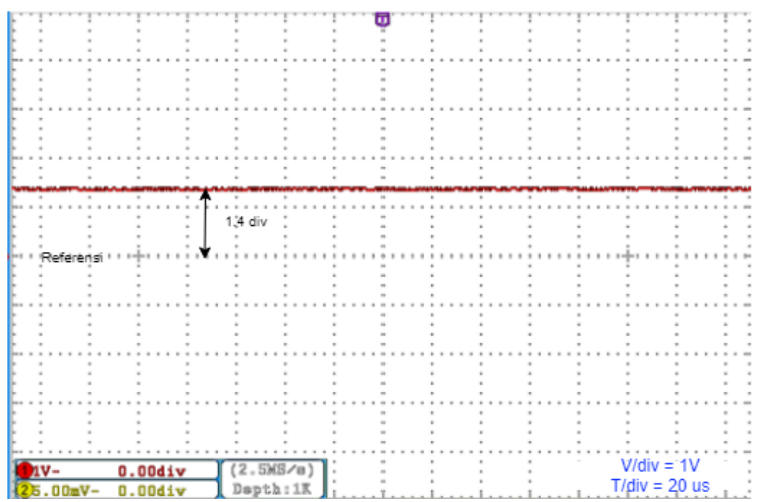

Gambar 15. Gelombang tegangan keluaran sensor tegangan dengan $\mathrm{V} / \mathrm{div}=1 \mathrm{~V}$

Berdasarkan Gambar 15 nilai tegangan keluaran sensor tegangan yang menuju pin analog A0 mikrokontroler sebesar 1,4 div, sehingga dapat dihitung besaran tegangan menggunakan probe dengan faktor pengali $\mathrm{x} 1$ adalah:

$$
\begin{aligned}
V_{\text {pin } A 0}= & 1.4 \mathrm{div} \times 1 \mathrm{~V} / \operatorname{div} \times 1 \\
& =1,4 \mathrm{volt}
\end{aligned}
$$

Nilai tegangan 1,4 volt adalah nilai tegangan Vout dari sensor tegangan. Nilai perbandingan tegangan hasil pengukuran dengan tegangan yang terbaca pada sensor ditunjukkan pada Tabel 1. 
Tabel 1. Perbandingan tegangan hasil pengukuran dengan tegangan sensor

\begin{tabular}{cccc}
\hline $\begin{array}{c}\text { Data } \\
\text { ke- }\end{array}$ & $\begin{array}{c}\text { Tegangan } \\
\text { pengukuran } \\
\text { (V) }\end{array}$ & $\begin{array}{c}\text { Tegangan yang } \\
\text { terbaca pada sensor } \\
\text { (V) }\end{array}$ & $\begin{array}{c}\text { Deviasi } \\
\text { (V) }\end{array}$ \\
\hline 1 & 0.17 & 0.16 & 0.01 \\
2 & 1.15 & 1.14 & 0.01 \\
3 & 1.46 & 1.45 & 0.01 \\
4 & 2.56 & 2.55 & 0.01 \\
5 & 3.48 & 3.48 & 0 \\
6 & 4.41 & 4.46 & 0.05 \\
7 & 5.55 & 5.55 & 0 \\
8 & 6.36 & 6.34 & 0.02 \\
9 & 7.64 & 7.65 & 0.01 \\
10 & 8.69 & 8.72 & 0.03 \\
\hline
\end{tabular}

Berdasarkan Tabel 1, didapatkan deviasi rata-rata pembacaan sensor tegangan sebesar 0,015 volt. Deviasi tersebut disebabkan karena pada Gambar 4.20 dapat dilihat nilai tegangan yang masuk ke pin A0 masih terdapat ripple (riak) tegangan. Riak tegangan tersebut mempengaruhi nilai ADC yang terbaca oleh mikrokontroler, sehingga pembacaan nilai tegangan keluaran buck converter menjadi kurang presisi.

\subsection{Pengujian Konverter DC-DC tipe Buck}

3.2.1. Pengujian Konverter DC-DC tipe Buck tanpa Umpan Balik

Pengujian ini dilakukan untuk mengetahui kinerja efisiensi konverter Buck tanpa umpan balik terhadap perubahan nilai duty cycle. Pengaturan duty cycle dilakukan manual potensiometer. Efisisensi buck converter dapat dicari dengan menghitung daya input dan daya output pada buck converter dengan beban pengujian sebesar $15.32 \Omega$ dengan menggunakan persamaan sebagai berikut.

$$
\text { Efisiensi }=\frac{\text { Daya Output }}{\text { Daya Input }} \times 100 \%
$$

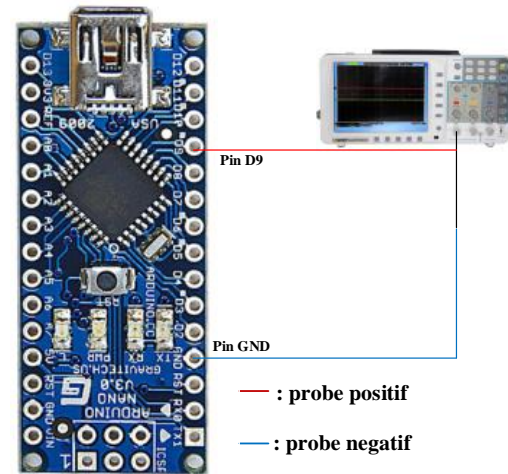

Gambar 16. Pengujian PWM keluaran Arduino Nano tanpa umpan balik

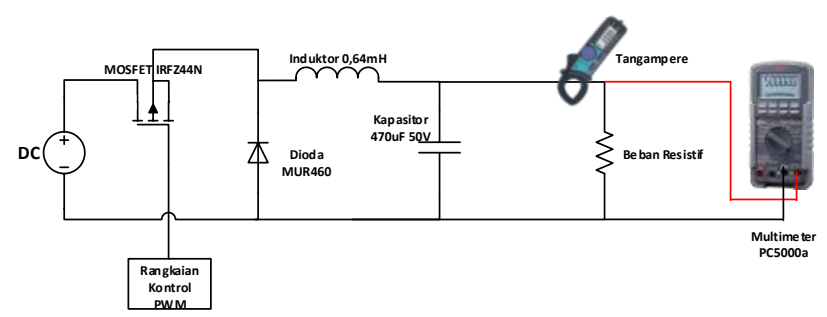

Gambar 17. Pengujian buck converter tanpa umpan balik tegangan

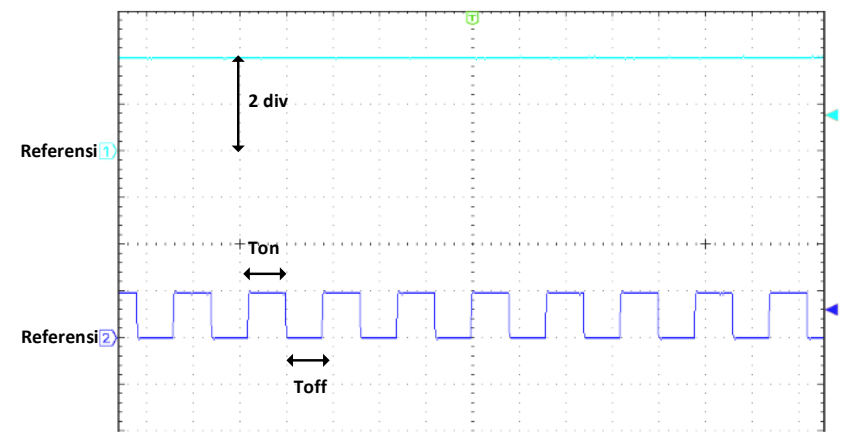

Gambar 18. Gelombang tegangan keluaran saat duty cycle $50 \%$, beban $15 \Omega$. V/div $=2 \mathrm{~V}, \mathrm{~T} / \mathrm{div}=$ $5 \mathrm{~ms}$.

Gambar 18 menunjukkan gelombang sinyal PWM (gelombang warna biru) ketika nilai duty cycle 50\%. Sedangkan untuk nilai tegangan keluaran pada nilai duty cycle tersebut adalah sebesar 2 div, sehingga dapat dihitung besaran tegangan keluaran menggunakan probe dengan faktor pengali $\mathrm{x} 1$ adalah:

$$
\begin{aligned}
\mathrm{V}_{\text {OUT }} & =2 \operatorname{div} \times 2 \mathrm{~V} / \operatorname{div} \times 1 \\
& =4 \text { volt }
\end{aligned}
$$

Sementara itu, nilai tegangan yang terbaca pada multimeter sebesar 4,51 volt. Berdasarkan hasil pengujian buck converter tanpa umpan balik dengan variasi duty cycle didapatkan data pengukuran sebagai berikut.

\begin{tabular}{|c|c|c|c|c|c|c|c|}
\hline $\begin{array}{c}\text { Duty } \\
\text { Cycle } \\
(\%)\end{array}$ & $\begin{array}{l}\mathrm{I}_{\mathrm{N}} \\
(\mathrm{A})\end{array}$ & $\begin{array}{l}V_{\text {IN }} \\
(V)\end{array}$ & $\begin{array}{l}\text { lout } \\
\text { (A) }\end{array}$ & $\begin{array}{l}\text { VoUt } \\
(\mathrm{V})\end{array}$ & $\begin{array}{l}P_{\text {IN }} \\
\text { (W) }\end{array}$ & $\begin{array}{l}\text { Pout } \\
\text { (W) }\end{array}$ & $\begin{array}{c}\eta \\
(\%)\end{array}$ \\
\hline 10 & 0.005 & 9.95 & 0.03 & 0.536 & 0.04 & 0.01 & 36.95 \\
\hline 20 & 0.022 & 9.95 & 0.09 & 1.462 & 0.21 & 0.13 & 63.78 \\
\hline 30 & 0.048 & 9.94 & 0.15 & 2.363 & 0.47 & 0.36 & 76.36 \\
\hline 40 & 0.094 & 9.94 & 0.22 & 3.458 & 0.93 & 0.77 & 82.53 \\
\hline 50 & 0.152 & 9.93 & 0.29 & 4.511 & 1.50 & 1.32 & 87.47 \\
\hline 60 & 0.238 & 9.93 & 0.37 & 5.737 & 2.36 & 2.14 & 90.78 \\
\hline 70 & 0.30 & 9.92 & 0.42 & 6.484 & 2.97 & 2.74 & 92.37 \\
\hline 80 & 0.405 & 9.91 & 0.49 & 7.605 & 4.01 & 3.77 & 94.15 \\
\hline 90 & 0.50 & 9.9 & 0.56 & 8.57 & 4.95 & 4.80 & 97.05 \\
\hline
\end{tabular}

Tabel 2. Hasil pengujian buck converter tanpa umpan balik 


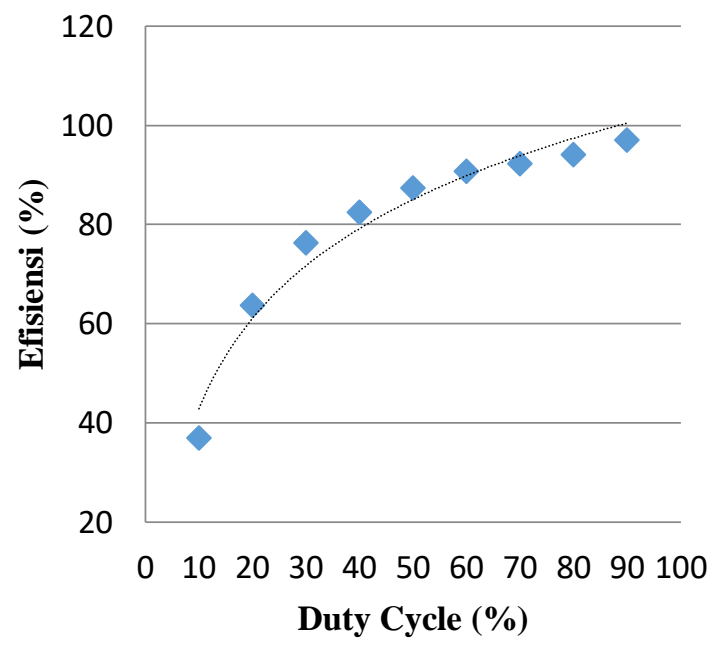

Gambar 19. Efisiensi buck converter tanpa umpan balik

Berdasarkan Tabel 2, buck converter sudah bekerja sesuai teori yang ada dengan nilai tegangan keluaran yang lebih rendah dari tegangan input. Nilai efisiensi rata-rata dari buck converter adalah 80,16\%. Nilai efisiensi tertinggi pada duty cycle $90 \%$ yaitu sebesar 97,05\%, sedangkan nilai efisiensi terendah didapat pada variasi duty cycle $10 \%$ yaitu sebesar $36,95 \%$. Efisiensi yang rendah pada saat nilai duty cycle kecil disebabkan pada saat tersebut siklus off dari MOSFET lebih banyak dibandingkan siklus on MOSFET. Hal tersebut menyebabkan dioda mengalami forward bias. Sedangkan saat nilai duty cycle tinggi, efisiensi dari buck converter akan tinggi karen siklus on MOSFET lebih lama dibandingkan siklus off-nya. Nilai siklus off yang lebih sedikit menyebabkan drop tegangan yang melewati dioda MURU1560 menjadi lebih kecil.

\subsubsection{Pengujian Konverter DC-DC tipe Buck dengan Umpan Balik Tegangan}

Pengujian ini dilakukan untuk mengetahui kinerja buck converter dengan umpan balik tegangan terhadap perubahan beban. Perubahan duty cycle PWM berdasarkan respon umpan balik tegangan.

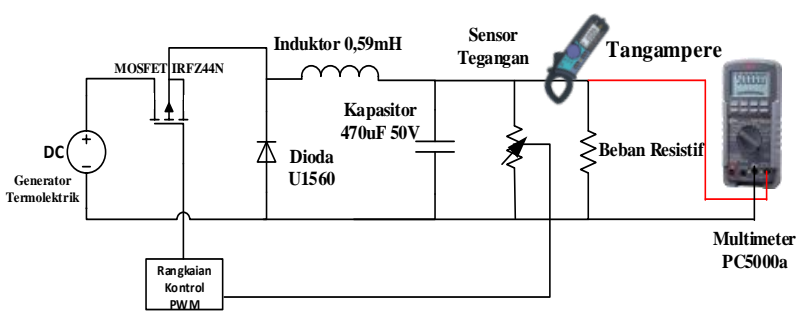

Gambar 20. Pengujian buck converter dengan umpan balik tegangan
Tabel 3. Hasil pengujian buck converter dengan umpan balik tegangan

\begin{tabular}{cccccc}
\hline $\begin{array}{c}\text { Duty Cycle } \\
(\%)\end{array}$ & $\begin{array}{c}\mathbf{V}_{\mathbf{I N}_{\mathrm{N}}} \\
(\mathbf{V})\end{array}$ & $\begin{array}{c}\mathrm{I}_{\mathrm{IN}} \\
(\mathbf{A})\end{array}$ & $\begin{array}{c}\mathbf{V}_{\text {OUT }} \\
(\mathbf{V})\end{array}$ & $\begin{array}{c}\mathrm{I}_{\text {OUT }} \\
(\mathbf{A})\end{array}$ & $\begin{array}{c}\text { Beban } \\
(\Omega)\end{array}$ \\
\hline 63 & 7.57 & 0.182 & 4.256 & 0.281 & 15 \\
53 & 8.61 & 0.147 & 4.03 & 0.26 & 15 \\
53 & 9.89 & 0.171 & 4.68 & 0.3 & 15 \\
45 & 10.65 & 0.134 & 4.19 & 0.27 & 15 \\
45 & 11.8 & 0.15 & 4.68 & 0.31 & 15 \\
40 & 12.62 & 0.13 & 4.46 & 0.29 & 15 \\
41 & 13.79 & 0.144 & 4.91 & 0.32 & 15 \\
63 & 7.57 & 0.182 & 4.256 & 0.281 & 15 \\
\hline
\end{tabular}

Tabel 4. Efisiensi buck converter dengan umpan balik tegangan.

\begin{tabular}{ccc}
\hline $\begin{array}{c}\text { Daya Input } \\
\text { (W) }\end{array}$ & $\begin{array}{c}\text { Daya Output } \\
\text { (W) }\end{array}$ & $\begin{array}{c}\text { Efisiensi } \\
(\%)\end{array}$ \\
\hline 1.38 & 1.20 & 86.80 \\
1.27 & 1.05 & 82.78 \\
1.69 & 1.40 & 83.01 \\
1.43 & 1.13 & 79.27 \\
1.77 & 1.45 & 81.96 \\
1.64 & 1.29 & 78.83 \\
1.99 & 1.57 & 79.12 \\
\hline
\end{tabular}

Berdasarkan Tabel 3, nilai tegangan keluaran mampu dijaga pada rentang nilai 4-5 $\mathrm{V}$ dengan nilai rata-rata tegangan output sebesar 4.458 volt. Nilai rata-rata efisiensi dari buck converter dengan umpan balik tegangan yaitu sebesar $81.68 \%$. Nilai dari efisiensi buck converter memiliki perbedaan untuk rentang nilai tegangan input yang berbeda.Nilai efisiensi rata-rata dengan umpan balik tegangan lebih tinggi dibandingkan dengan efisiensi rata-rata tanpa menggunakan umpan balik efisiensi tanpa umpan balik 80,16\%.

\section{Kesimpulan}

Konverter arus searah tipe buck converter dengan rangkaian pemicu mikrokontroler Arduino telah berhasil direalisasikan dengan pengaruh pengujian buck converter tanpa umpan balik tegangan adalah tegangan keluaran akan semakin mendekati tegangan masukan apabila duty cycle yang dihasilkan oleh rangkaian kontrol Arduino hampir mencapai $100 \%$ serta pengaruh pengujian buck converter dengan umpan balik tegangan, nilai tegangan keluaran dapat dijaga konstan sebesar 4-5 V. Nilai tegangan keluaran dijaga konstan untuk tegangan input dan beban yang berubah-ubah . Nilai rata-rata efisiensi dari buck converter dengan umpan balik tegangan yaitu sebesar $81.68 \%$. Nilai efisiensi rata-rata dengan umpan balik tegangan lebih tinggi dibandingkan dengan efisiensi rata-rata tanpa menggunakan umpan balik (efisiensi tanpa umpan balik 80,16\%. 


\section{Referensi}

[1]. S. C. Puspita, H. Sunarno, dan B. Indarto, "Generator Termoelektrik untuk Pengisisan Aki," J. Fis. Dan Apl., vol. 13, no. 2, pp. 84-87, 2017.

[2]. M. Pandita, N. Agung, dan M. Facta, "Catu Daya Arus Searah Terkontrol Jenis Buck Converter Untuk Pemisah Magnetik Dalam Konveyor", Jurnal Transient, vol. 5, no. 3, September 2016, ISSN : 2302-9927.

[3]. S. Eko, N. Agung, dan M. Facta, "Penggunaan Konverter Jenis Buck Dengan Pemutus Tegangan Otomatis Untuk Pengisi Akumulator", Jurnal Transient, vol. 4, no. 1, Maret 2015, ISSN: 2302-9927,52.

[4]. L. W. Cahyadi, T. Andromeda, dan M. Facta, "Kinerja Konverter Arus Searah Tipe Buck Converter dengan Umpan Balik Tegangan Berbasis IC TL494."
[5]. E. Setiawan, M. Facta, A. Nugroho, "Penggunaan Konverter Jenis Buck dengan Pemutus Tegangan Otomatis untukk Pengisi Akumulator."

[6]. HEXFET Power MOSFET, "IRFZ44N," $P d$ - 94053, vol. PD-94053, no. PD-94053, pp. 1-9, 2001

[7]. ON Semiconductor, "MUR1520 - Switch-mode Power Rectifiers,", pp. 1-8, 2014.

[8]. W. H. Daniel, Power Electronics Handbook, The Mcgraw-Hill Companies, Indiana, Valparasio Universtity, 2011.

[9]. Arduino nano specification, Radiospares.

[10]. Toshiba, "TLP250," vol. 5, pp. 1-7, 2017. 